\title{
INFLUENCE OF CHECK DAMS ON BED SEDIMENT IN THE TENCZYŃSKI STREAM
}

\author{
Karol Plesiński, Kamil Suder \\ Faculty of Environmental Engineering and Land Surveying, University of Agriculture in Krakow, al. Mickiewicza 21, 31-120 Krakow
}

\begin{abstract}
Aim of research

The aim of this research was to analyse an influence of check dams on granulometry of bed sediments in their impact area. Necessary data was obtained during field measurements carried out in May 2017. Sediment was collected using the Wolman's method. Data collected through this method were used to determine granulometric curves, granulometric parameters and shapes of grains forming riverbed sediment in the region of the studied objects.
\end{abstract}

\section{Material and methods}

Sediment measurements were carried out below and above the check dams through the Wolman's method. Grain size curves were then plotted, granulometric and sedimentological parameters were calculated. In addition, grain size and shape were determined using the Sneed and Folk methods.

\section{Results and conclusions}

The number of discoid grain pebbles increased below the dam in relation to the level above the dam. In the material collected below the dam there was a smaller number of spindle-shaped grains than in the material collected above the dam. Above the dam there are larger amounts of finer material than below. This may be related to the retention of even small grains of pebbles in the dam reservoir, in which flow velocity is lower than in the riverbed, thus depositing of carried material. On the other hand, in the lower station, due to the increased water flow velocity, small debris is washed away, and in the bottom of the bed only thick fractions are found.

Keywords: check dam, bed sediment, granulometric parameters, pebbles shape, Tenczyński Stream

\section{INTRODUCTION}

The special role of water management is to maintain various aquatic ecosystems in high ecological quality, which among others include rivers and mountain streams that are extremely sensitive to human impact and activity. It is extremely important, when assessing ecological status of a watercourse, to take into account hydromorphological evaluation of water flow. Small changes in an ecosystem or in hydromorphological conditions in rivers and mountain streams carry different ecological consequences (Bartnik and Książek, 2007). Due to their importance for the entire national water network special attention should be devoted to watercourses. Various morphological processes take place in such watercourses, providing suitable environment for biological life development. The amount of transported sediment depends on water flow volume. It is important to know grain size of transported rubble, especially when assessing erosive capaci-

凶e-mail:kplesinski@ar.krakow.pl 
ty, carrying capacity and efficiency of a river. Check dams construction could pose as one of examples of human interference affecting bed sediment.

Check dam is a hydrotechnical object erected across a riverbed to a height above the HHW (the Highest High Water). A dam has a frontal wall with a spillway (throat) that crosses a riverbed. Below it has an energy dissipation basin, which can take form of a dry basin or have a water cushion. A basin with a threshold at its mouth is surrounded by side walls. Above a dam is a reservoir bowl, where the material transported by a river accumulates. Thus, its correct size is a significant design parameter for this type of object (Ratomski, 2002). Schematic structure of a dam in a longitudinal and transversal cross-section is shown in Fig. 2.

The purpose of a dam is to stop excessive sediment traffic, reduce longitudinal slope in a watercourse above a dam and reduce flow rate. Heede and Mufich (1973) state that a dam retains $50 \%$ of original volume of sediment. An additional task is to protect slopes and stop intensive washing of riverbanks that can cause landslides.

In order to situate a dam it is necessary to thoroughly learn the structure and shape of a riverbed and its surrounding area. Effectiveness of a check dam increases with a growth of volume of a created reservoir and approximating a dam to an estuary. Hard and stable soil provides excellent conditions for such hydrological structure. Substrate quality and shapes of riverbed and valley are significant determinations of dam height. Low dams are built in wide valleys, while high dams are built in deeper and narrowed valleys.

A dam in a plan view usually looks like an arc with a typical deflection of $\mathrm{f}=0.05 \mathrm{R}$ (radius of dam axis). An arched shape enforces static strength of a structure. Downstream slope of a dam body is inclined to allow the stone material transported by water to fall into a basin without reaching the wall surface, and the wall from upstream slope is vertical. Therefore, a cross-section through dam body adopts a trapezium shape. Wall thickness at a base and spillway of dam body depends on static calculations that take into account forces affecting the structure, foundation conditions and a type of material intended for construction (Wołoszyn et al., 1994).

From a throat of a body towards edges stretch the dam's arms, which pose as dam body's extensions on both sides. Since they are usually made of the same material as dam's body or soil embankments, they have similar structure. Their task is to close off riverbed by connecting edges with main body. There is a need for designing soil embankments, when arms length is twice the spillway length of a throat (Ratomski, 2013, Wołoszyn et al., 1994). Often, lowered body of a dam with a fishpass can be a solution. It combines both hydrotechnical and biological approach by maintaining ecological continuity of a watercourse and allowing aquatic organisms to travel freely (Radecki-Pawlik et al., 2017).

Size and number of slots that are built into the dam's body have to enable a pass of low and medium flows. These can be located in the dam's body vertically (slot check dam) or horizontally (slit check dam). However, in case of high water they should have capacity to stop transporting large stones that could damage a station below a dam and further located structures and sections of a stream.

Below the dam's body an outlet basin is built. Its purpose is to dissipate kinetic energy of falling water and absorb impact. An energy dissipation basin consists of a base plate made of material resistant to damage and guidance system. There is a possibility of constructing dry wells with built-in water stream dispersion structures. Length of dry wells depends on type of material it is made of and a height of a dam. Height of side handlebars (side walls) depends on a height of hydraulic jump and wall inclination from an upstream slope. Width of a basin is equal to or greater than width of spillway throat (Ratomski, 2013; Wołoszyn et al., 1994).

In addition to a classic wall structure of check dam, there are also similar structures with a lowered spillway throat, but without draining slots (solid check dam) and with vertical stilts in a spillway (compound check dam) (Piton and Racking, 2015). There are also special dams made of steel lattices (lattice check dam), spread nets (net check dams) and slanted or vertical grates (sectional check dams) (Armanini et al., 2006; Twaróg, 2014; Piton and Racking, 2015; Silva, 2016).

The aim of paper is to analyse an influence of check dams on granulometry of bed sediments in their impact area. Data necessary for this was obtained during field measurements, which were carried out in May 2017. The sediment was collected using the Wolman method. Data collected through this method were used to determine granulometric curves, setting granulometric 
parameters and defining shapes of grains forming river rubble in the region of studied facilities.

\section{DESCRIPTION OF RESEARCH AREA AND FACILITIES}

The Tenczyński Stream Valley is located in the southern part of Poland in the Małopolskie Voivodeship, Myślenice poviat, Lubień municipality. Geographically, the catchment is located in the Carpathian Region, in the Western Carpathians, in the macroregion called the Western Beskids, which includes the mezoregion of Island Beskid (Kondracki, 2011).

The Tenczyński Stream is a fourth-order watercourse with a total length of $6.41 \mathrm{~km}$. It is a right-bank tributary of the Lubieńka Stream flowing into the Raba River at an altitude of $339 \mathrm{~m}$ a.s.l. There is mainly coarse rock material, and gravel and stone fractions at the bed of the watercourse. The Tenczyński Stream catchment area covers $23.96 \mathrm{~km}^{2}$, located between two massifs: it is surrounded by the Lubon massif to the south, where the largest peak is Lubon Wielki with a height of $1022 \mathrm{~m}$ a.s.l. At the foot of this peak, at a height of about $970 \mathrm{~m}$ a.s.l., the stream has its source, while from the north of the catchment is bordered by a range of mountains, of which the highest peak is the Szczebel - 977 m a.s.l. Steep slopes of the mountains are covered with forests, whereas areas with moderate slopes situated lower are utilised for agricultural purposes. Areas located directly at the riverbed have been developed with residential, handicraft and service buildings. In the upper part of the stream, on a slope of the Szczebel massif, there is an area of surface exploitation of sandstone deposits. The stream catchment with marked dams is shown in Fig. 1.

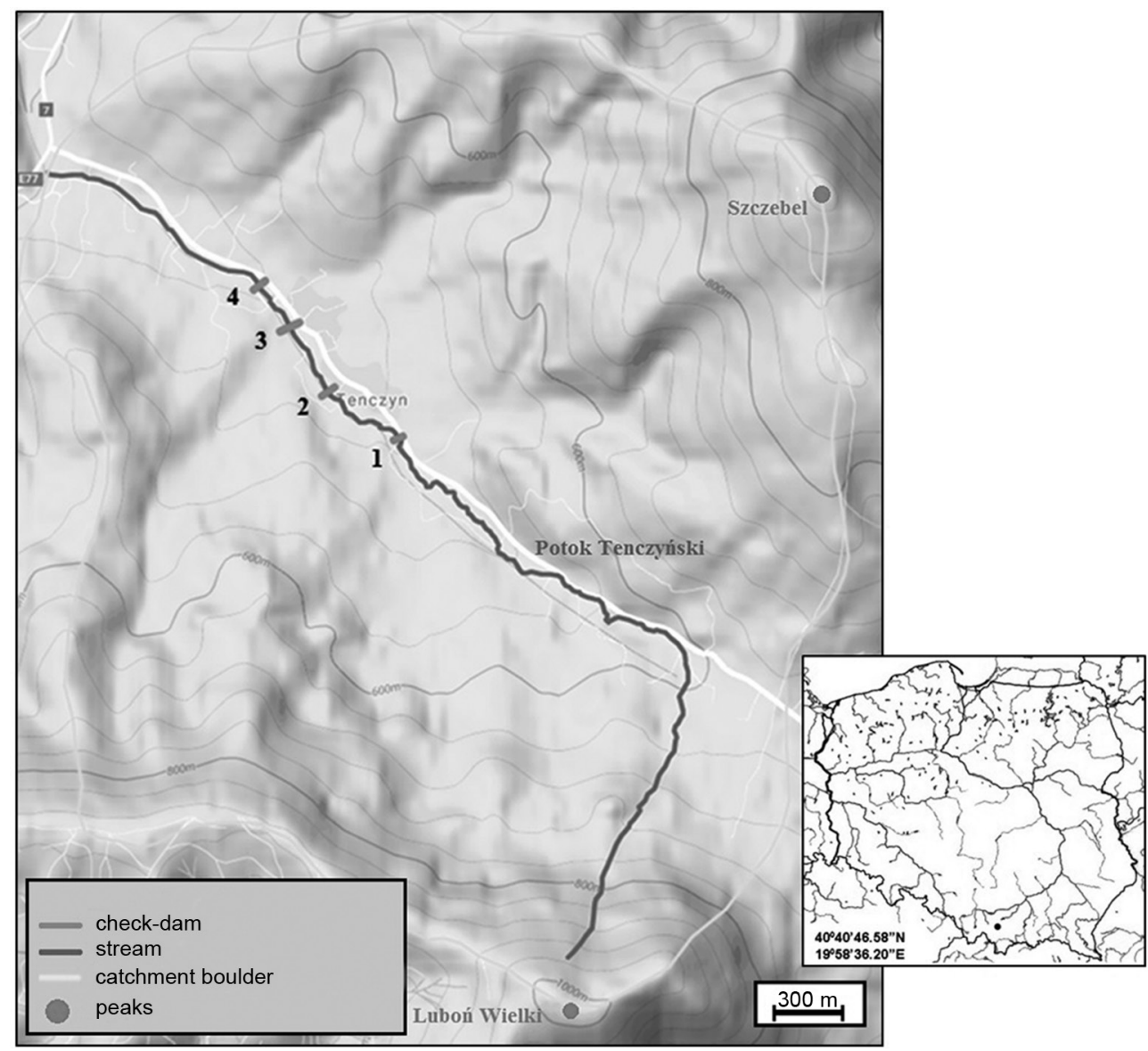

Fig. 1. The Tenczyński Stream catchment with check dams 
In the valley of the Tenczyński Stream in the first decade of the 21 st century, a complex of four check dams of III class structures was built (Wołoszyn et al., 1994). From the mouth, upstream of the watercourse, the first building, i.e. dam no. 4, was placed on $1+200 \mathrm{~km}$ of the stream length. The dam no. 3 was located about $200 \mathrm{~m}$ above the previous one, i.e. it was erected on the $1+400 \mathrm{~km}$ of the stream. The dam no. 2 was built on the $1+700 \mathrm{~km}$ of the stream. The dam no. 1 located on the $2+200 \mathrm{~km}$ of the watercourse was situated highest in the catchment (Bogacz, 2018).

All dams are made of the same material and have a similar construction (see: Fig. 2, Table 1), which according to the classification of Wehrmann and others (2006) are a type of multiple small slot dams, class III, with many, small drainage slots (Piton and Racking, 2015). These dams are artificial barriers that block migration possibilities of organisms living in the stream's valley causing a significant deteriora- tion of ecological status of the watercourse (Bogacz, 2018)

Currently, the reservoirs of all dams are significantly filled with rubble due to accumulation of material carried by the stream, reduction of longitudinal slope of the stream and decreasing water flow velocity above the dam. At a lower station of the overdeepening, energy dissipation basins at the base of the dam remain unsilted. Banks on the regulated section below the structure are stabilized with concrete slabs. The whole structure does not show any serious defects. Concrete enforcement of slopes slowly blends into the surrounding area by gradually overgrowing with small vegetation. The energy dissipation basin was completed with a concrete threshold reinforced across the entire width with a riffles formed of natural boulders. In the area between the overdeepening of the basin and the threshold, accumulates material transported by water, which then has been collected for research (Bogacz, 2018).
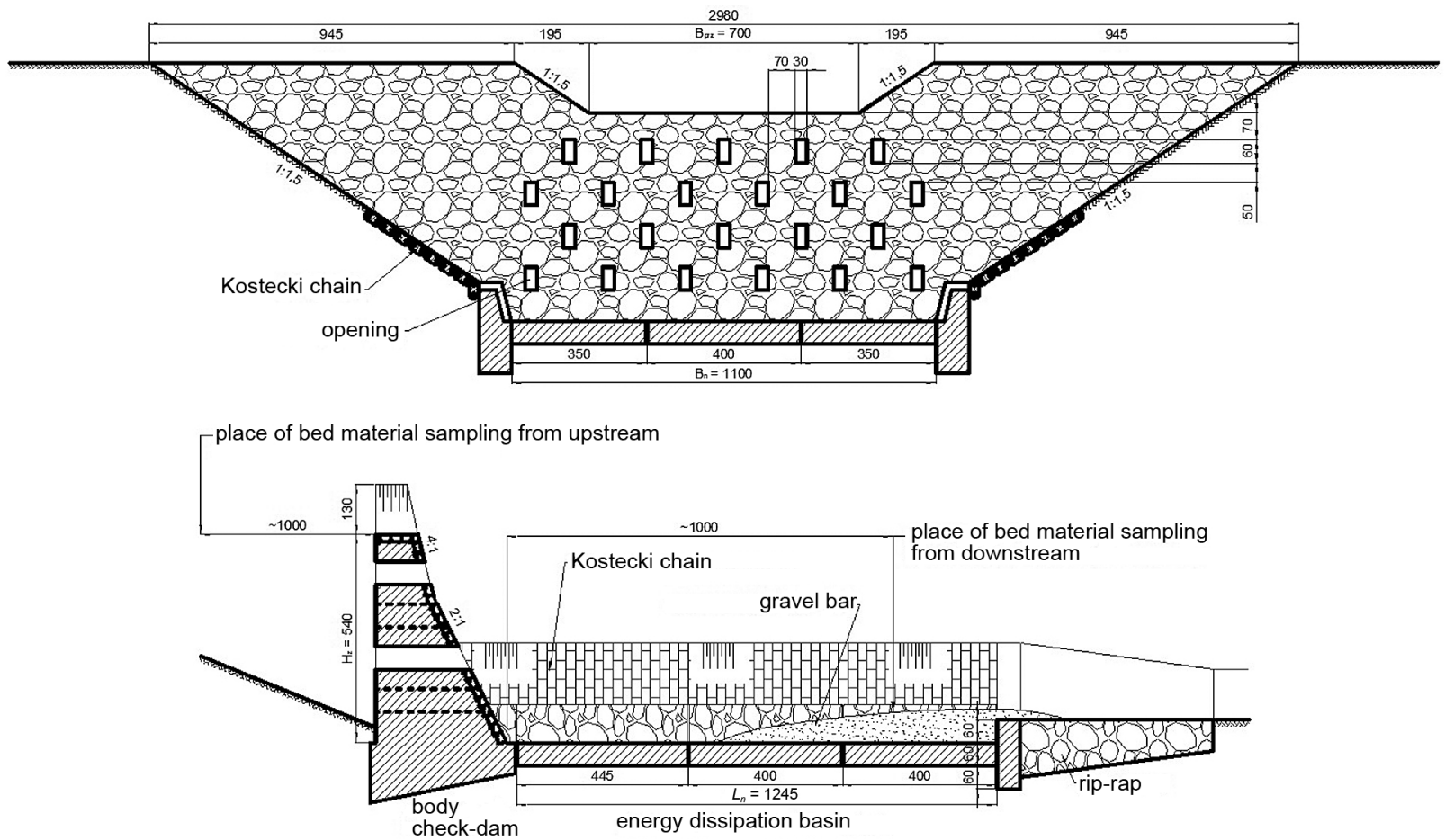

Fig. 2. Scheme of no. 4 check dam (author's work based on Malik et al. 2002) 
Table 1. Technical parameters of check dams (based on Malik et al. 2002)

\begin{tabular}{|c|c|c|c|c|c|}
\hline Number of check-dam & Units & 1 & 2 & 3 & 4 \\
\hline Location in stream channel (from mouth) & $\mathrm{km}$ & $2+200$ & $1+700$ & $1+400$ & $1+200$ \\
\hline Size of openings & $\mathrm{cm}$ & \multicolumn{4}{|c|}{$30 \times 60$} \\
\hline Rows number of openings & - & 3 & & 4 & \\
\hline Columns number of openings & - & 9 & 11 & 9 & 11 \\
\hline Number of openings & - & 14 & 20 & 18 & 22 \\
\hline Spillway width, $B_{p r z}$ & $\mathrm{~m}$ & & 6 & & 7 \\
\hline Spillway height & $\mathrm{m}$ & \multicolumn{4}{|c|}{1.3} \\
\hline Slope of side spillway & - & \multicolumn{4}{|c|}{$1: 1.5$} \\
\hline Check-dam height, $\mathrm{H}_{\mathrm{z}}$ & $\mathrm{m}$ & 4.4 & 6.1 & 5.1 & 5.4 \\
\hline Width of check-dam with wings, $B_{z a p}$ & $\mathrm{~m}$ & 36.0 & 43.0 & 42.3 & 38.5 \\
\hline Drop height of water & $\mathrm{m}$ & 3.8 & 5.5 & 4.5 & 4.8 \\
\hline Width of energy dissipation basin near to check-dam, $B_{n}$ & $\mathrm{~m}$ & & 10 & & 11 \\
\hline Width of energy dissipation basin near to step & $\mathrm{m}$ & & 6 & & 7 \\
\hline Length of energy dissipation basin, $L_{n}$ & $\mathrm{~m}$ & 11.95 & 11.10 & 11.55 & 12.45 \\
\hline Rip-rap length below energy dissipation basin & $\mathrm{m}$ & \multicolumn{4}{|c|}{5} \\
\hline Depth of energy dissipation basin & $\mathrm{m}$ & \multicolumn{4}{|c|}{0.6} \\
\hline Slope of downstream body check-dam - upper part & - & \multicolumn{4}{|c|}{$4: 1$} \\
\hline Slope of downstream body check-dam - lower part & - & \multicolumn{4}{|c|}{$2: 1$} \\
\hline
\end{tabular}

\section{RESEARCH METHODOLOGY}

\section{Sediment measurements}

Sediment was measured below and above a check dam. In order to confirm repeatability of the structure's impact on the granulometric distribution of sediments, measurements were carried out in vicinity of all four dams located in the Tenczyński Stream Valley using the Wolman method (1954), which consists in collecting in a straight line of 100 grains of pebbles and measuring their length, width and height. The material was taken at a distance of $10 \mathrm{~m}$ from the body of each structure from the upper and lower station. As for the upper station, it was bottom of the riverbed, while for the lower station - the collecting site was in relation to a transversal point bar created at the end of the energy dissipation basin, sediment often eroding onto the final threshold of the basin and the beginning of the pits. The straight line was set transversely to the riverbed, so that pebbles could be collected not only from the main stream, but also from the lateral areas of the riverbed.

\section{Analysis of grain size}

To determine equivalent diameter $\left(d_{i}\right)$ of a single pebble, its three dimensions were measured: $d_{1}$ - length; $d_{2}-$ width; $d_{3}-$ height. Diameter of a given object is represented by the following formula (Plesiński, 2018):

$$
d_{i}=\left(d_{1} \cdot d_{2} \cdot d_{3}\right)^{\frac{1}{3}}[\mathrm{~mm}],[\mathrm{m}]
$$

Determining effective diameter $d_{m}$ and average diameter (mean) $d_{a v r}$ of a given sample allowed for further calculations, which resulted in the following 
diameters: $d_{5}, d_{10}, d_{16}, d_{20}, d_{25}, d_{50}, d_{60}, d_{75}, d_{80}, d_{84}, d_{90}$, i $d_{95}[\mathrm{~mm}]$ and granulation curve of the sample was generated.

Effective diameter was calculated according to the following formula (Plesiński, 2018):

$$
d_{m}=\sum d_{i} \cdot p_{i} \cdot\left(\sum p_{i}\right)^{-1}[\mathrm{~mm}],[\mathrm{m}]
$$

given that:

$d_{m}$ - effective diameter [mm], [m],

$p_{i}, d_{i}$ - appropriately read percentage of the i-th fraction and diameter of the i-th fraction from the curve of sifting.

The formula was used to calculate the average diameter (Plesiński, 2018):

$$
d_{\text {avr }}=\left(d_{84} \cdot d_{50} \cdot d_{16}\right) \cdot 3^{-1}[\mathrm{~mm}],[\mathrm{m}]
$$

\section{Analysis of grain shapes according to Sneed and Folk}

Three dimensions of axes were obtained for each pebble: long axis $-\mathrm{a}$, medium axis $-\mathrm{b}$, short axis $-\mathrm{c}$, which were used to determine grain shape by flat-

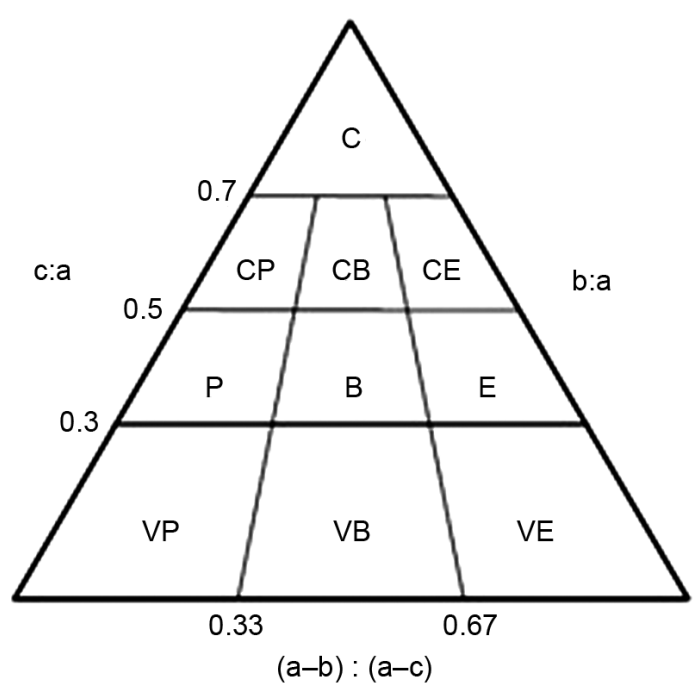

Fig. 3. Grain shape according to Sneed and Folk given that: $\mathrm{C}$ - compact (spherical), CP - compact-platy, CB - compact-bladed, CE - compact-elongate, $\mathrm{P}$ - platy (discoid), B - bladed (ellipsoid), E - elongate (spindle), VP - veryplaty, VB - very-bladed, VE - very-elongate ness, elongation and sphericity indicators according to Sneed and Folk (1958). Analysis was made possible by the TRI-PLOT program constructed by David Graham (Loughbough University) and Nicholas Midgley (Liverpool John Moores University) in a Microsoft Excel package (Graham and Midgley, 2000). This program supports determining the grain shape according to the classification of Sneed and Folk (1958), which is also graphically illustrated in triangular diagrams. The Sneed and Folk classification is based on defining the limit length proportions of three axes relative to each other and distinguishes ten grain shapes found in river rubble (see: Fig. 3).

\section{Analysis of granulometric parameters}

To determine the sorting index, an equation was applied according to the Tras formula (Radecki-Pawlik, 2011):

$$
S_{0}=\sqrt{\frac{d_{84}}{d_{16}}}
$$

Degree of sorting was obtained using the Hazen formula (Radecki-Pawlik, 2011):

$$
u=\frac{d_{60}}{d_{10}}
$$

The Knoroz formula was applied to calculate diversity index (Radecki-Pawlik, 2011):

$$
\varepsilon=\frac{d_{95}}{d_{5}}
$$

The dominance feature, i.e. uniformity index, was calculated according to the Kollis formula (Radecki-Pawlik, 2011):

$$
C_{d}=\frac{d_{90} \cdot d_{10}}{d_{50}^{2}}
$$

Roughness height was calculated using the formula (Gładki, 1976):

$$
K_{s}=2.54 \cdot d_{80}
$$

The Maning roughness coefficient was determined in accordance with the formula (Radecki-Pawlik, 2011): 


$$
\begin{gathered}
n=\frac{1}{K} \\
K=\frac{21.1}{\left(d_{m}\right)^{\frac{1}{6}}}
\end{gathered}
$$

\section{RESEARCH RESULTS}

\section{Interpretation of granulometric parameters}

Tab.2. shows indicators and parameters describing the collected material. The largest effective diameter $d_{m}=54 \mathrm{~mm}$ and average diameter $d_{a v r}=50 \mathrm{~mm}$ was noted at the station below the dam no. 1 located in the upper reaches of the stream. The smallest value of effective diameter as well as average diameter was noted above the dam no. 3 and they were respectively: $d_{m}=$ $14 \mathrm{~mm}, d_{\text {avr }}=10 \mathrm{~mm}$.

Fig.4. presents granulometric curves for eight sediment measurement sites, i.e. above and below each of the four dams. The percentage content of individual fractions was recorded based on the obtained granulation curves. The tested sediment consisted of two types of fractions: gravel fraction and stony fraction.
The course of the granulometric curves confirmed that the characteristic diameters of material taken above the dam are smaller than the material that was collected below the dam.

With regard to the first dam, $20 \%$ of the fractions were pebbles up to $20 \mathrm{~mm}$ in diameter, obtained above the dam, while below the dam - aggregate with such a diameter was $10 \%$ of the fraction. Grain content with a diameter less than $40 \mathrm{~mm}$ was about $74 \%$ above the dam and about $44 \%$ below. The granulometric curves for measuring stations in vicinity of the 2nd dam were similar to those for the 1 st dam. The curves for both stations were very similar only on the section with grain content above $95 \%$., where there was a fraction with a diameter larger than $80 \mathrm{~mm}$. The largest distance from the curves could be read for effective diameter of $30 \mathrm{~mm}$. The fraction with a diameter smaller than $30 \mathrm{~mm}$ in the lower station of the 2 nd dam constituted about $37 \%$, while for the upper station it accounted for $55 \%$. Above the $3 \mathrm{rd}$ dam, the largest accumulation of fine rock material was observed, as $80 \%$ of the fraction contained material with a diameter of less than $15 \mathrm{~mm}$. Below the basin, material with such a diameter constituted only $5 \%$ of the sediment accumulated there. For stations near the 4th barrage, granulometric

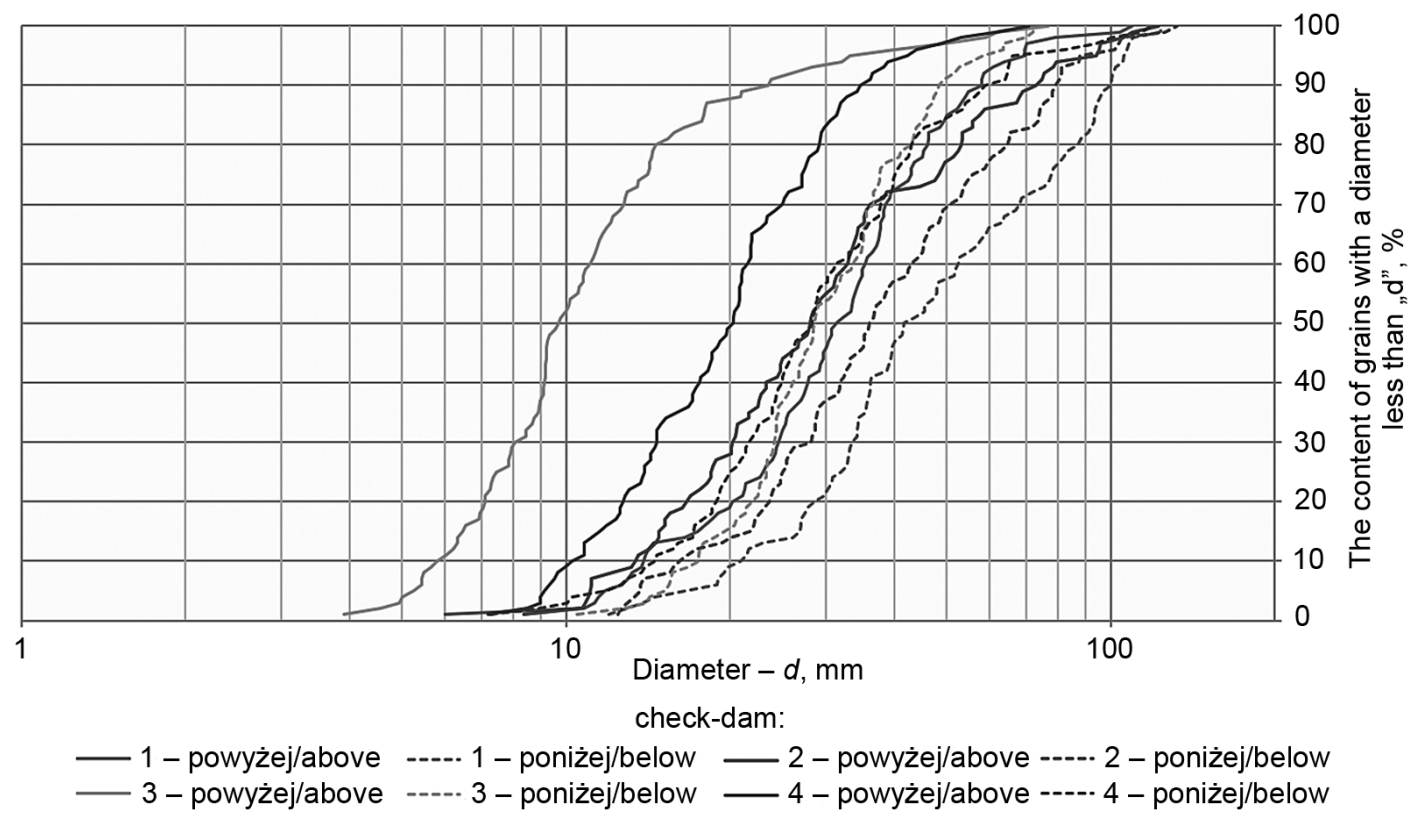

Fig. 4. Granulometric curve 
Table 2. Diameter of bed sediment and granulometric parameters in measurement points

\begin{tabular}{|c|c|c|c|c|c|c|c|c|}
\hline & \multicolumn{2}{|c}{ Check-dam no. 1 } & \multicolumn{2}{c}{ Check-dam no. 2 } & \multicolumn{2}{c|}{ Check-dam no. 3 } & \multicolumn{2}{c|}{ Check-dam no. 4 } \\
& Above & Below & Above & Below & Above & Below & Above & Below \\
\hline $\mathrm{d}_{\mathrm{sr}}$ & 32 & 50 & 32 & 39 & 10 & 30 & 20 & 29 \\
\hline $\mathrm{d}_{\mathrm{m}}$ & 35 & 54 & 36 & 44 & 14 & 32 & 22 & 34 \\
\hline $\mathrm{k}_{\mathrm{s}}$ & 117 & 221 & 135 & 165 & 38 & 109 & 74 & 109 \\
\hline $\mathrm{S}_{0}$ & 1.37 & 1.56 & 1.63 & 1.50 & 1.41 & 1.29 & 1.39 & 1.41 \\
\hline $\mathrm{u}$ & 2.50 & 2.48 & 2.54 & 2.69 & 1.83 & 1.89 & 2.20 & 2.07 \\
\hline$\varepsilon$ & 5.75 & 6.18 & 8.55 & 6.29 & 6.60 & 3.87 & 4.67 & 5.50 \\
\hline $\mathrm{C}_{\mathrm{d}}$ & 0.84 & 1.19 & 1.21 & 0.98 & 1.44 & 1.03 & 0.88 & 1.13 \\
\hline $\mathrm{n}$ & 0.0271 & 0.0291 & 0.0272 & 0.0282 & 0.0233 & 0.0267 & 0.0251 & 0.0270 \\
\hline $\mathrm{d}$ & 1.65 & 1.86 & 1.93 & 1.82 & 1.60 & 1.50 & 1.61 & 1.70 \\
\hline
\end{tabular}

curves were arranged along their entire length at an equal distance. The curve for the lower station was slightly shifted to the left in relation to the curve for the upper station. Diameters of no more than $22 \mathrm{~mm}$ accounted for $60 \%$ of the material collected above the 4th dam, while for the station below the dam - $60 \%$ of the fraction consisted of grains up to $31 \mathrm{~mm}$. However, above the dam no. 4. grains over $31 \mathrm{~mm}$ accounted for almost $85 \%$ of total sediment. The granulometric analysis of sediment proves that the tested check dams complex works properly and prevents transporting river material.

However, after a comparative analysis of pebble grain size for samples taken above and below the dams it can be concluded that the dams do not work properly, because the upper stations hold finer material than in the lower stations. This relates to every dam: no. 1: $d_{50}=31 \mathrm{~mm}$ for the upper station and $d_{50}=42 \mathrm{~mm}$ for the lower station; no. $2: d_{50}=28 \mathrm{~mm}$ and $d_{50}=36 \mathrm{~mm}$, respectively; no. 3: $d_{50}=10 \mathrm{~mm}$ and $d_{50}=29 \mathrm{~mm}$, respectively; no. 4: $d_{50}=20 \mathrm{~mm}$ and $d_{50}=28 \mathrm{~mm}$, respectively. However, drawing such a conclusion would be a mistake, as Gawor and Ratomski (1991) claim. All analysed dams have a wide dam cross-section of $B_{z a p} / B_{p r z}>2$. In this type of dams, the initial functioning period is characterized by retention of thick sediments. At the same time, the process of depositing fine dust and clay particles is several times faster (Gawor and Ratomski, 1991). This causes a quick silting of a reservoir, hence the material taken from the upper stations consisted much finer granulation than the material taken from the lower stations - more so that the samples were obtained only from a surface layer. Gawor and Ratomski (1991) argue that floatable particles sometimes occupy from $1 / 2$ to $2 / 3$ of the bowl length. This is due to the significant variation in speed resulting from filling cross-sections with various geometries. This process is extremely intense when freshets drop, i.e. when flow through drainage slots is often hindered as a result of their clogging up with rock and vegetative material. Deposition process of fine rubble fractions is also accelerated by vegetation in the reservoir's bowl and on terraces, which additionally causes a reduction in flow rate. Sediment is characterized by a large admixture of organic matter (Gawor and Ratomski, 1991). Silting of check dam reservoirs is also accelerated by their large drop. Then, these structures cause high damming of high flows, which results in increasing active flow cross-sections in the reservoir's bowl and velocity decrease (Gawor and Ratomski, 1991).

If there is a complex of several check dams, analysing an operation of a single structure without considering its construction type and character of its riverbed and valley may lead to wrong conclusions. In such cases, the entire cascade of structures should be 
analysed. If we analyse all structures as one object, then we will notice that sediment grain size decreases with along the watercourse.

In the upper station, sediment grain size decreases from $d_{20}=20 \mathrm{~mm}, d_{50}=31 \mathrm{~mm}$ and $d_{80}=46 \mathrm{~mm}$ for the dam no. 1, through $d_{20}=17 \mathrm{~mm}, d_{50}=28 \mathrm{~mm}$ and $d_{80}=53 \mathrm{~mm}$ for dam no. 2 , to $d_{20}=7 \mathrm{~mm}, d_{50}=10 \mathrm{~mm}$ and $d_{80}=15 \mathrm{~mm}$ for dam no. 3 . Only the sample taken above the dam no. $4\left(d_{20}=13 \mathrm{~mm}, d_{50}=20 \mathrm{~mm}\right.$ and $d_{80}=29 \mathrm{~mm}$ ) features a thicker sediment than the sample for dam 3, but still finer than for dam no. 2. The increase in the diameter of pebble grains in the upper station of the lowest located dam (no. 4) in relation to the dam located above it (no. 3) may result from the fact that the watercourse is at this point subjected to very large anthropopressure. On the right bank of the stream there is a water mill, which causes logjams on a right mid-channel bar. Transporting logs for further processing requires heavy equipment for levelling a riverbed. Therefore, there is a larger increase in flow velocity, than it would be observed in natural conditions, resulting in leaching of fine grains and leaving thicker ones. Whereas, on the left side of the riverbed there is a school, which young people sometimes after lessons interfere in the bottom of the watercourse, destroying its pavement and using pebbles to create artificial gravel-stone formations. Damaging naturally produced bed sediment makes it easier to start and propel river material motion.

In the lower station, sediment grain size decreases from $d_{20}=29 \mathrm{~mm}, d_{50}=42 \mathrm{~mm}$ and $d_{80}=87 \mathrm{~mm}$ for the dam no. 1, through $d_{20}=24 \mathrm{~mm}, d_{50}=36 \mathrm{~mm}$ and $d_{80}=65 \mathrm{~mm}$ for dam no. 2 , and $d_{20}=22 \mathrm{~mm}$, $d_{50}=29 \mathrm{~mm}$ and $d_{80}=43 \mathrm{~mm}$ for dam no. 3 , to $d_{20}=19 \mathrm{~mm}, d_{50}=28 \mathrm{~mm}$ and $d_{80}=43 \mathrm{~mm}$ for dam no. 4. Similar values for samples taken below dams no. 3 and 4 may indicate that the process of stopping river sediment through dam no. 4 may be ineffective. Of course, it is necessary to take into account the very large impact of human factors on the watercourse above the dam no. 4, which certainly affects the lower station. Hence, delivering an objective assessment of the dam closest to the stream mouth is extremely difficult.

Interesting research on bed sediments deposited in bowls of check dam reservoirs was conducted by Hassanli et al. (2009). Their research was carried out on 5 cascades with 3 selected structures in each (situ- ated the highest in the cascade, in the middle and the lowest) in a catchment of the Droodzan River located in the province of Fars in Iran. The body of the analysed dams was made of stone boulders, usually a height of a structure was small - without basin and drainage slots, but with a possibility for water to seep through slits between stones. Structures analyzed by Hassanli et al. (2009) were located on 4 ephemeral rivers and one perennial with spring supply. Obtained sediment consisted mainly of sand, dust and clay fractions, i.e. particles a lot smaller in diameter than the material taken from the Tenczyński Stream. Despite very different conditions, the research from the Carpathian stream confirmed a tendency noted by Hassanli et al. (2009) that the lower a dam is in a cascade, the smaller sediment is in a reservoir. In presented here research, with an exclusion from the analysis of dam no. 4 located at the lowest of the cascade, where there is a large negative impact of local population on sediments deposited in the reservoir, it can be concluded that sediment size accumulated in reservoir bowls decreases as the riverbed approaches its estuary. The paper of Hassanli et al. (2009) also presents a tendency of decreasing sediment size in check dam reservoirs, but because the sediment is very fine (average diameter is $d_{50}=0.15-2.00 \mathrm{~mm}$ ), difference between sediments received from far dams is small, amounting to $\Delta d_{50}=0.35-1.05 \mathrm{~mm}$ (on the Tenczyński Stream difference was $\Delta d_{50}=21 \mathrm{~mm}$ ). Moreover, it (Hassanli et al., 2009) shows that the tendency of sediment size decrease in individual dams does not have to be constantly decreasing and locally may even be increasing.

$K_{\mathrm{s}}$, also called roughness height, characterizes surface roughness of wetted circuit (see: Table 2). For each dam, larger values of roughness height were found in the lower station. However, a drop in $k_{s}$ rate was recorded below the dams, thus surface roughness of sediment of each dam decreased with respect to the previous one.

Sorting coefficient according to Trask $\left(S_{0}\right)$ was classified between 1.29 for the station below the dam no. 3 , and 1.50 for the station below the dam no. 2 , which according to Tab. 1.indicates that the obtained material was well sorted in all measuring points (see: Table 2).

Sorting degree according to the Hazen $(\mathrm{u})$ formula provided with the lowest result of 1.83 at the station 
above the 3rd dam, and the highest sorting degree of 2.69 below the 2 nd dam (see: Table 2).

The Knoroz index $(\varepsilon)$ describing varied granularity assumed values from 3.87 (below the 3rd dam) to 8.55 (above the 2nd dam), which allows to conclude that in the obtained material there was a large variation in size of material (see: Table 2).

Stations above the 1st dam and at the station below the 2nd dam affirmed a dominance of fine fraction, as indicated by the Kollis indicator $C_{d}<1$, while in the remaining stations the $C_{d}>1$ indicator displayed an advantage of thick fractions (see: Table 2). The largest rate was at the station above the 3rd dam, amounting $C_{d}=1.44$, and the smallest value was obtained above the 1st dam, amounting $C_{d}=0.84$.

The Manning roughness coefficient ranged between 0.0233 for the upper 3rd dam station and 0.0291 for the lower 1st dam station (see: Table 2).

Standard deviation (SD) values of the bed sediment oscillated between 1.50 and 1.93 (see: Table 2).

\section{Analysis of grain shape and quantity}

The classification according to Sneed and Folk (1958) was applied to describe and compare grain shape. Quantities of a given grain shape on a given dam station are presented in Tab. 3, while Fig.5. shows percentage distribution of shapes according to Sneed and Folka.
Qualification of grain shape made by the Sneed and Folka method has proven that the most common grain shape among the 800 samples taken in the vicinity of the 4 dams was a very ellipsoidal shape. There were 135 samples of aggregates in this shape. 129 samples had ellipsoidal shape and 122 samples had a very discoid shape. Spherical and slightly discoid grains occurred 41 times, as did spherical and slightly ellipsoidal grains. The least -28 grains - were grains in a spherical shape.

During research no spherical shape grains above the dam no. 1 was found. At the station above the dam no. 3 , the spherical shape constituted $8 \%$ of river sediment. Spherical and slightly discoid grains constituted from $7 \%$ (at the station above the dam no. 4) to $3 \%$ (at the station below the dam no. 2) river sediment. Spherical and slightly ellipsoidal pebbles accounted for $8 \%$ (at the station above the 2nd dam) to 3\% (at the station above the 1st dam). Spherical and slightly spindle-shaped rubble was found most often at the station above the dam no. 1 and constituted $9 \%$ of sediment, while the least frequently it appeared at the station above the dam no. 3 , where it accounted for $3 \%$ of sediment. Discoid shaped aggregates accounted for $22 \%$ of sediment above the dam no. 4 , while the smallest percentage was noted above the 2 nd dam and constituted $9 \%$ of sediment. Ellipsoidal shape is most easily

Table 3. Grain shape distribution according to Sneed and Folk

\begin{tabular}{lccccccccc}
\hline & \multicolumn{2}{c}{ Check-dam no. 1 } & \multicolumn{2}{c}{ Check-dam no. 2 } & \multicolumn{2}{c}{ Check-dam no. 3 } & \multicolumn{2}{c}{ Check-dam no. 4 } \\
\hline & Above & Below & Above & Below & Above & Below & Above & Below \\
\hline Compact, C & 0 & 2 & 7 & 1 & 8 & 7 & 4 & 2 \\
\hline Compact-platy, CP & 4 & 4 & 5 & 3 & 6 & 4 & 7 & 5 \\
\hline Compact-bladed, CB & 3 & 4 & 8 & 7 & 5 & 5 & 5 & 4 \\
\hline Compact-elongate, CE & 9 & 7 & 6 & 4 & 3 & 6 & 4 & 4 \\
\hline Platy, P & 14 & 20 & 9 & 16 & 14 & 11 & 22 & 11 \\
\hline Bladed, B & 10 & 17 & 18 & 17 & 11 & 23 & 17 & 16 \\
\hline Elongate, E & 12 & 9 & 9 & 13 & 20 & 12 & 8 & 9 \\
\hline Very-platy, VP & 10 & 18 & 15 & 16 & 11 & 17 & 14 & 21 \\
\hline Very-bladed, VB & 29 & 17 & 13 & 19 & 14 & 11 & 11 & 21 \\
\hline Very-elongate, VE & 9 & 2 & 10 & 4 & 8 & 4 & 8 & 7 \\
\hline
\end{tabular}




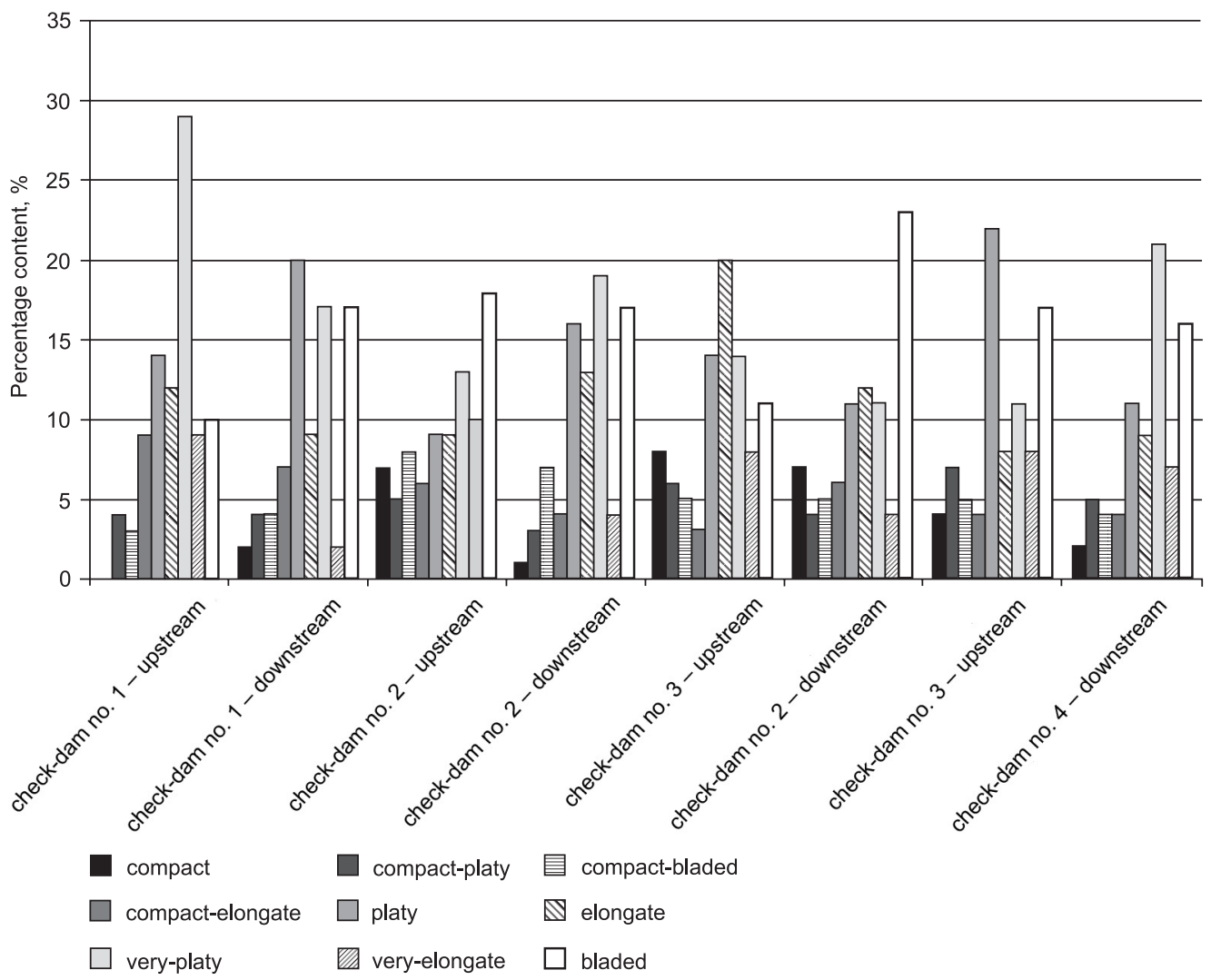

Fig. 5. Grain shape according to Sneed and Folk

observed below the 3rd dam, where it equalled 23\% of sediment. It occurred the least frequently above the first dam $-10 \%$ of sediment. Spindle-shaped grains accounted for $20 \%$ of granulation above the $3 \mathrm{rd}$ dam, while the smallest quantity was recorded at the station above the dam no. 4 , where it was $9 \%$ of the aggregate present there. Very discoid stones ranged from $11 \%$ above the 3 rd dam to $21 \%$ of sediment below the dam no. 4. A very ellipsoidal shape dominated above the 1 st dam constituting $29 \%$ of river sediment, while the smallest number of such shape was found at the station below the dam no. 3 and above the dam no. 4 , where it constituted $11 \%$ of sediment located there. Very spindle-shaped grains occurred at the station above the 2 nd dam and constituted up to $10 \%$ of sediment. They occurred the least at the station below the first dam constituting $2 \%$ of the sediment bed located there.

The graphic presentation (see: Fig. 6,7) of grain shape results above and below the dam was used to perform an analysis of the impact of the dam no. 1 on the sediment. Strongly ellipsoidal pebbles had the largest drops in number - decrease by $12 \%$. In turn, the largest changes taking into account an increase in number were noted for aggregates of strongly discoid shape $-8 \%$.

For the dam no. 2, considering a growth in number of a given grain shape, the highest increase was recorded for discoid shaped pebbles, by $7 \%$, followed by strongly ellipsoidal shape, $6 \%$, spindle-shaped, $4 \%$, and for strongly discoid aggregates about $1 \%$. Spherical and strongly spindle-shaped grains were observed to have the largest changes in number - decrease by $6 \%$ (see: Fig. 8, 9).

The largest increase in number of a given grain shape, when analysing the dam no. 3 , was recorded for spindle grains, by $12 \%$. In the case of spherical and slightly ellipsoidal grains, no changes were observed. Spindle-shaped pebbles decreased the most, by $8 \%$. 


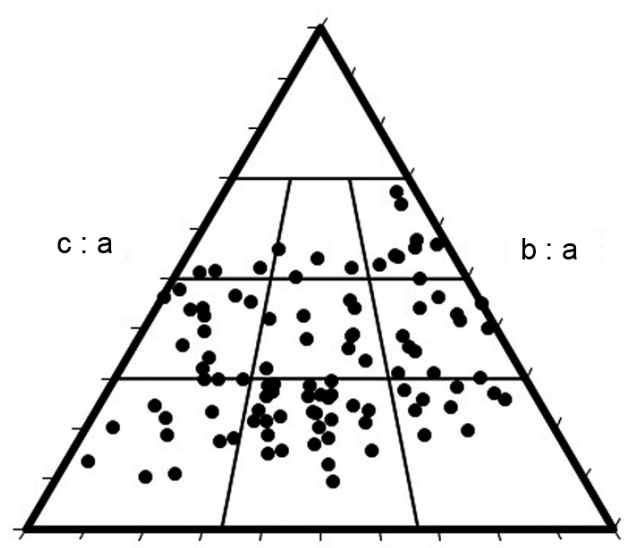

$(a-b) /(a-c)$

Fig. 6. Grain shape graph for upstream of check dam no. 1

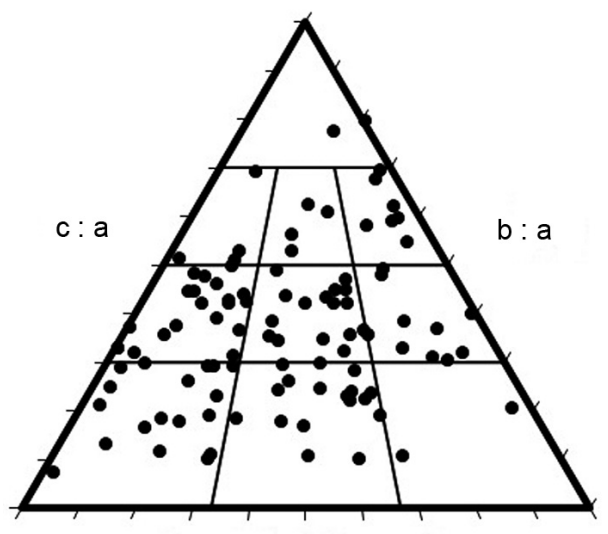

$(a-b) /(a-c)$

Fig. 7. Grain shape graph for downstream of check dam no. 1

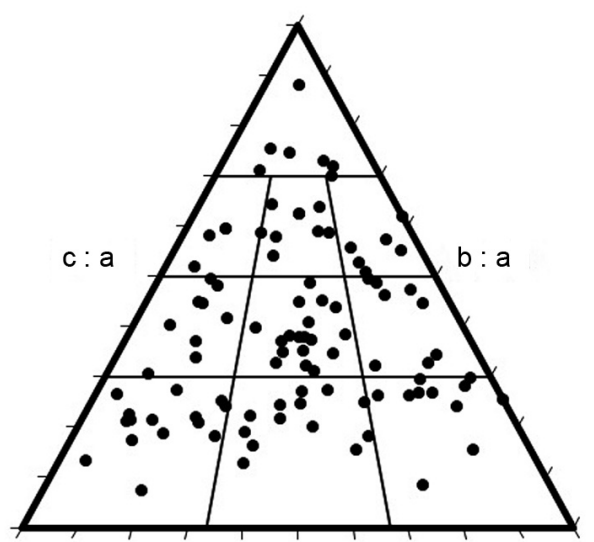

$(a-b) /(a-c)$

Fig. 8. Grain shape graph for upstream of check-dam no. 2

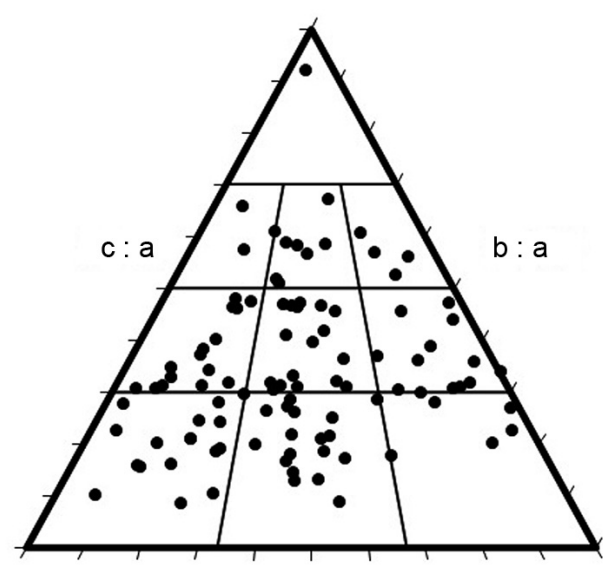

$(a-b) /(a-c)$

Fig. 9. Grain shape graph for downstream of check-dam no. 2

Second were spherical and strongly spindle-shaped grains, with a drop of $4 \%$. The number of pebbles of a strongly ellipsoidal and discoid shape also decreased, by $3 \%$ (see: Fig. 10, 11).

The largest increase in number of a given grain shape for dam no. 4 was recorded for pebbles in a strongly ellipsoidal shape, by as much as $10 \%$, then for strongly discoid grains, by $7 \%$. The largest changes, considering decrease in number of a given grain shape, were featured by discoid pebbles - with as much drop as $11 \%$ Pebbles with spherical and spherical with slightly discoid shape grains showed a decrease by $2 \%$. The number of aggregates with spherical and slightly ellipsoidal, ellipsoidal and strongly spindle-shaped grains decreased by only $1 \%$ (see: Fig. 12, 13).

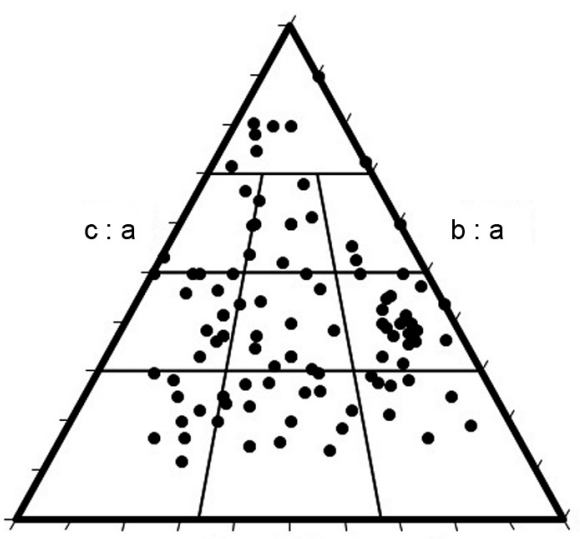

$(a-b) /(a-c)$

Fig. 10. Grain shape graph for upstream of check-dam no. 3 


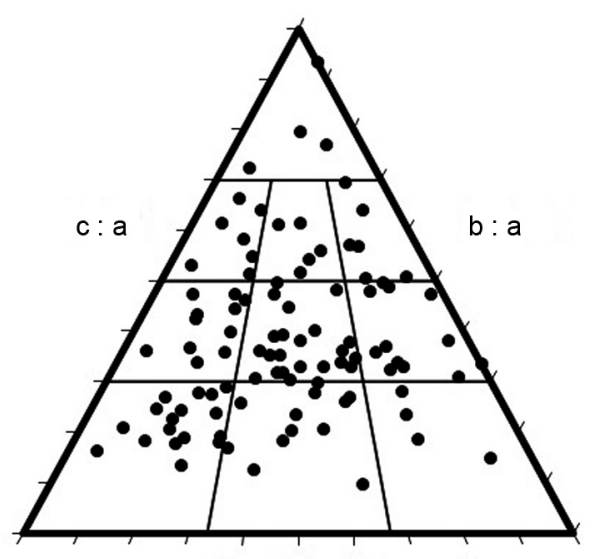

$(a-b) /(a-c)$

Fig. 11. Grain shape graph for downstream of check-dam no. 3

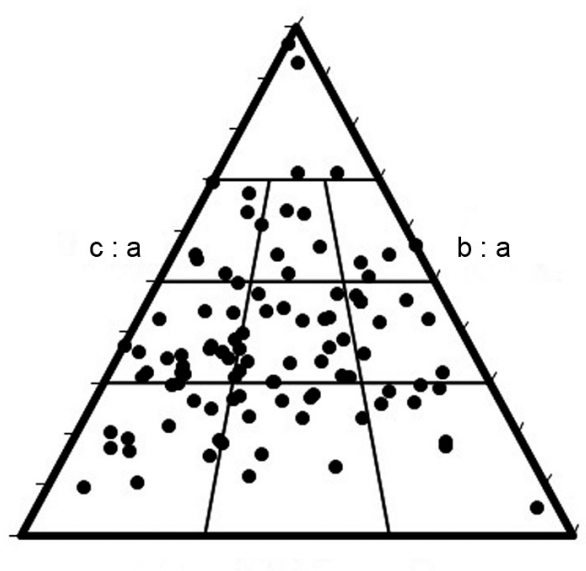

$(a-b) /(a-c)$

Fig. 12. Grain shape graph for upstream of check-dam no. 4

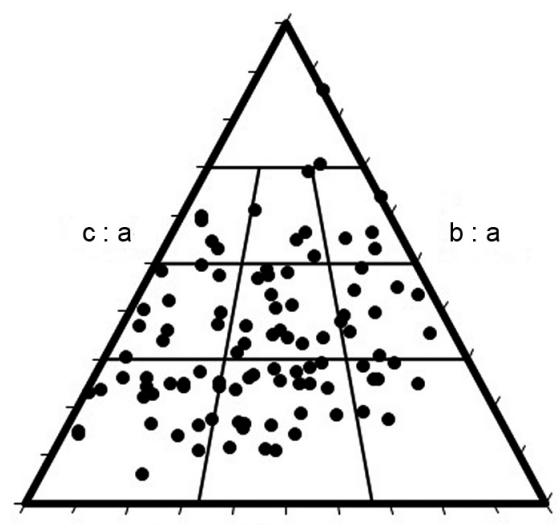

$(a-b) /(a-c)$

Fig. 13. Grain shape graph for downstream of check-dam no. 4

\section{CONCLUSIONS}

The following conclusions can be drawn:

1. A complex of four check dams located on the Tenczyński Stream is operating properly. The size of the sediment grains in the riverbed near the dam no. 4 is much smaller than at the dam no. 1 . This may indicate a proper operation of the entire complex, although single dams can work less effectively. The dam no. 4 displays low efficiency, because below it there is a slightly smaller rubble $\left(\Delta d_{20}=3 \mathrm{~mm}, \Delta d_{50}=1 \mathrm{~mm}\right.$ and $\left.\Delta d_{80}=0 \mathrm{~mm}\right)$ than below the dam no. 3 .

2. When assessing the operation of several check dams, all structures located on the watercourse (or in a given regulatory section) should be taken into account, as analysing them separately may result in giving erroneous conclusions. Analysis of the suspended river sediment in reservoir bowls and the sediment located in lower stations should include all structures situated on the watercourse (or at least on a given section / regulatory section) considering their types and construction, as well as geomorphological conditions of the riverbed and the shape of the valley river.

3. In all places of sediment measurement, the material consisted mainly of discoid grain shape, ranging from $36 \%$ to $54 \%$ of total. Spherically shaped pebbles had the least share, ranging from $5 \%$ to $19 \%$. The number of discoid grain pebbles increased below the dam in relation to the number above the dam. There was a smaller number of spindle-shaped grains in the material collected below the dam than above the dam.

4. There are larger amounts of finer material above the dam than below. It may be related to stopping small grain pebbles in the dam reservoir, in which flow velocity is lower than in the riverbed, thus causing the carried material to settle. On the other hand, in the lower station, due to increased water flow velocity, small debris is washed away, and in the bottom of the watercourse only thicker fractions are left.

5. Higher roughness heights $\mathrm{k}_{\mathrm{s}}$ occurred in the lower station of each dam, although below a dam the roughness of sediment surface of each dam was lower than in the previous one. 
6. The value of the Trask sorting index $\left(S_{0}\right)$ indicated proper sorting of bed sediments at all measuring points. It was similar for Hazen (u) sorting degree, values of which indicated well-sorted material. Various size of material was registered on the basis of the Knoroz index $(\varepsilon)$. The rate of the Kollis index $C_{d}<1$ indicated a dominance of fine fraction in the upper station of the first dam and in the bed below the 2 nd dam. At the remaining stations, the value of $C_{d}>1$ showed more thick fractions.

\section{REFERENCES}

Armanini, A., Dellagiacoma, F., Ferrari, L. (2006). From the check dam to the development of functional check dams. (In:) Armanini A., Di Silvio G. (eds.) Fluvial Hydraulics of Mountain Regions. Lecture Notes in Earth Sciences, 37, 331-344.

Bartnik, W., Książek, L. (2007). Regulacja rzek i potoków górskich w warunkach równowagi hydrodynamicznej. Infrastruktura i Ekologia Terenów Wiejskich, 4(2), 1526.

Bogacz, J. (2018). Zmiany granulometrii w korycie Potoku Tenczyńskiego w rejonie zapór przeciwrumowiskowych. Uniwersytet Rolniczy w Krakowie, Praca magisterska, maszynopis.

Gawor, A., Ratomski, J. (1991). Konstrukcja zapór przeciwrumowiskowych a efektywność ich działania. Gospodarka Wodna, 2, 46-48.

Gładki, H. (1976). Opory i prędkość przepływu w korytach rzek górskich na przykładzie karpackich dopływów Wisły. Zeszyty Naukowe Akademii Rolniczej w Krakowie, seria Rozprawy Habilitacyjne, 118.

Graham, D. J., Midgley, N. G. (2000). Graphical representation of particle shape using triangular diagrams: an excel spreadsheet method. Technical communication. Earth Surface Processes and Landforms, 25, 1473-1477.

Hassanli, A.M., Nameghi, A.E., Beecham, S. (2009). Evaluation of the effect of porous check dam location on fine sediment retention (a case study). Environmental Monitoring and Assessment, 152, 319-326.

Heede, B.H., Mufich, J.G. (1973). Functional relationship and a computer program for structural gully control. Journal of Environmental Management, 1, 321, 344.

Kondracki, J. (2011). Geografia regionalna Polski. Warszawa: PWN.
Malik, M., Kawalec, T., Olbrych, M., Podstawa, P., Wątroba, R., Biel, B. (2002). Systematyczna zabudowa potoku Tenczynka w km 4+800 $\div 7+100 \mathrm{w}$ m. Tenczyn - w ramach usuwania skutków powodzi z lipca 2001 r. Projekt, Kraków

Piton, G., Recking, A. (2015). Design of Sediment Traps with Open Check Dams. I: Hydraulic and Deposition Processes. Journal of Hydraulic Engineering, 142(2), $1-16$.

Plesiński, K. (2018). Variability of the river bed system and morphology in the region of the block ramp impact (the case of the Porębianka river), Acta Scientiarum Polonorum, Formatio Circumiectus, 17(1), 79-93.

Radecki-Pawlik, A. (2011). Hydromorfologia rzek i potoków górskich. Działy wybrane, Kraków: Wydawnictwo Uniwersytetu Rolniczego w Krakowie.

Radecki-Pawlik, A., Plesiński, K., Radecki-Pawlik, B. (2017). Rozkład prędkości oraz naprężeń stycznych w komorach przepławki typu wielkokomorowego. Acta Scientiarum Polonorum, Formatio Circumiectus, 16(1), 149-159.

Ratomski, J. (2002). Intensywność zalądowania zapór przeciwrumowiskowych. Gospodarka Wodna, 12, 511-515.

Ratomski, J. (2013). Zabudowa zlewni i koryt potoków górskich. Kraków: Wydawnictwo Politechniki Krakowskiej.

Silva, M., Costa, S., Canelas, R.B., Pinheiro, A.N., Cardoso, A.H. (2016). Experimental and numerical study of slitcheck dams. International Journal of Sustainable Development and Planning, 11(2), 107-118.

Sneed, E. D., Folk, R. L. (1958). Pebbles in the lower Colorado River, Texas, a study in particle morphogenesis. Journal of Geology 66, 114-50.

Twaróg, B. (2014). Możliwości zastosowania elastycznych zapór przeciwrumowiskowych. Nowoczesne Budownictwo Inżynieryjne, 7-8, 62-67.

Wehrmann, H., Hübl, J., Holzinger, G. (2006). Classification of dams in torrential watersheds. Proc., Interpraevent Conf., Universal Academy Press, Tokyo, 829-838.

Wolman, M. G. (1954). A method of sampling coarse river-bed material. Eos Transactions American Geophysical Union, 35(6), 951-956.

Wołoszyn, J., Czamara, W., Eliasiewicz, R., Krężel, J. (1994). Regulacja rzek i potoków. Wrocław: Wydawnictwo Akademii Rolniczej we Wrocławiu. 


\section{WPLYW ZAPÓR PRZECIWRUMOWISKOWYCH NA OSADY KORYTOWE POTOKU TENCZYŃSKIEGO}

\section{ABSTRAKT}

\section{Cel pracy}

Celem publikacji jest analiza wpływu zapór przeciwrumowiskowych na granulometrię osadów korytowych w rejonie ich oddziaływania. Dane niezbędne do pracy pozyskano podczas pomiarów terenowych, które zostały zrealizowane w maju 2017 roku. Pobór rumowiska wykonano metodą Wolmana. Zebrane w ten sposób dane posłużyły do wyznaczenia krzywych granulometrycznych, ustalenia parametrów granulometrycznych oraz określenia kształtów ziaren tworzących rumowisko rzeczne w rejonie badanych obiektów.

\section{Materiał i metody}

Pomiary rumowiska realizowano poniżej oraz powyżej zapory przeciwrumowiskowej stosując metodę Wolmana. Następnie wykreślono krzywe uziarnienia, obliczono parametry granulometryczne i sedymentologiczne, takie jak: wskaźnik wysortowania Traska, stopień wysortowania Hanzena, wskaźnik różnoziarnistości Knoroza, wskaźnik jednostajności Kollisa, wysokość szorstkości, współczynnik szorstkości Manninga. Ponadto określono wielkość oraz kształt ziaren metodą Sneeda i Folka.

\section{Wyniki i wnioski}

We wszystkich miejscach poboru rumowiska materiał składał się głównie z ziaren o kształcie dyskoidalnym, stanowiły one od $36 \%$ do $54 \%$ wszystkich ziaren. Najmniej wystapiło otoczaków o kształcie sferoidalnym, ich udział mieścił się w przedziale od 5\% do 19\%. Liczebność otoczaków o kształcie ziaren dyskoidalnym wzrastała poniżej zapory w stosunku do stanu powyżej zapory. W materiale pobranym poniżej zapory występowała natomiast mniejsza ilość ziaren o kształcie wrzecionowatym, niż w materiale pobranym powyżej zapory. Powyżej zapory występują większe ilości drobniejszego materiału niż poniżej. Może być to związane z zatrzymywaniem nawet drobnych ziaren otoczaków w zbiorniku zapory, w którym prędkość przepływu jest mniejsza niż w korycie rzecznym, tym samym powodując deponowanie niesionego materiału. $Z$ kolei na stano-wisku dolnym, z powodu zwiększonych prędkości przepływu wody, drobne rumowisko jest wymywane, a w dnie koryta zostają tylko frakcje grubsze.

Słowa kluczowe: zapora przeciwrumowiskowa, osady korytowe, parametry granulometryczne i sedymentologiczne, kształt otoczaków, Potok Tenczyński 